\title{
Isolasi dan Identifikasi Jamur Xerofilik pada Jamu Serbuk Pegal Linu di Mojosongo, Surakarta
}

\author{
Isolation and Identification of Xerophilic Fungi in 'Pegal Linu' Powder Herb Medicine in \\ Mojosongo, Surakarta
}

\author{
Kartinah Wiryosoendoyo*, Nony Puspawati, dan Dewi Sulistyawati \\ Fakultas Ilmu Kesehatan Universitas Setia Budi Surakarta \\ *Corresponding author : kartinahws@yahoo.com
}

\begin{abstract}
ABSTRAK
Jamur xerofilik sering tumbuh pada produk yang kering, seperti jamu serbuk dan rempah-rempah (Askun dkk, 2007). Produk yang terkontaminasi jamur xerofilik berpotensi mengandung mikotoksin yang berbahaya bagi kesehatan. Penelitian ini bertujuan untuk mengisolasi dan mengidentifikasi keberadaan jamur xerofilik pada jamu serbuk pegal linu di Mojosongo, Surakarta.

Penelitian ini termasuk penelitian observasional, pengambilan sampel dilakukan secara random. Sampel jamu serbuk pegal linu diambil di wilayah Mojosongo, Surakarta terdiri dari 2 sampel jamu ber merk (sampel A dan B) dan 2 sampel jamu tidak ber merk (sampel C dan D). Inokulasi dilakukan dengan tehnik taburan pada media DG 18 (Dichloran 18\% Gliserol).

Dari hasil penelitian ini terbukti bahwa secara mikologis, jamu yang tidak ber merk belum tentu kualitasnya lebih rendah dibandingkan dengan jamu yang ber merk. Jumlah koloni pada jamu tidak ber merk lebih sedikit dibandingkan jumlah koloni pada jamu ber merk. Hasil inkubasi ke empat sampel jamu pegal linu semuanya menunjukkan adanya kontaminasi jamur xerofilik. Pada sampel A (ber merk) ditemukan ada 4 jenis jamur yaitu, E. chevalieri, E. amstlelodami, E. herbariorum dan E. repens. Jamur yang tumbuh pada sampel B (ber merk) ada 7 jenis yaitu, Eurotium repens, Eurotium chevalieri, Eurotium amstelodami, Aspergillus niger, Fusarium solani, Absidia corymbifera, dan Neosatorya fisheri. Jamur yang tumbuh pada sampel C (tidak ber merk) ada 6 jenis yaitu, Eurotium repens, A. candidus, A. niger, A. fumigatus, Moniliella suaveolens dan Epicoccum nigrum. Jamur yang tumbuh pada sampel D (tidak ber merk) ada 2 jenis yaitu, A. ochraceus dan A. terreus.
\end{abstract}

Kata kunci : xerofilik, jamu serbuk, pegal linu

\section{ABSTRACT}

Xerophilic fungi often grows on dry products, such as herbs and spices (Askun et al., 2007). Products contaminated with xerophilic fungi potentially contain mycotoxins that are harmful to health. This study aims to isolate and identify the presence ofxerophilic fungi in 'Pegal Linu' powder herb medicine in Mojosongo, Surakarta.

This study is observational research, sampling was done randomly. Sample of 'Pegal Linu' powder herb medicine taken in Mojosongo region, Surakarta consists of 2 samples of branded powder herb medicines (samples A and B) and 2 samples of unbranded powder herb medicines (samples $C$ and D). Inoculation was done by pour plate technic on DG 18 medium (Dichloran 18\% Glycerol).

From the results of this study proved that mycologically, unbranded powder herb medicines are not necessarily lower quality compared with powder herb medicines branded. The number of colonies in unbraned powder herb medicines are fewer than the number of colonies in branded powder herb medicines. The incubation of the four samples of powder herb medicines all showed the presence of xerophilic fungi contamination. In sample A (branded), found 4 types of fungi there are E. chevalieri, E. amstlelodami, E. herbariorum and E. repens. Fungi grown on sample B (branded) there are 7 species namely, Eurotium repens, Eurotium chevalieri, Eurotium amstelodami, Aspergillus niger, Fusarium solani, Absidia corymbifera, and Neosatorya fisheri. Fungi growing on sample C (no brand) there are 6 species namely, Eurotium repens, A. candidus, A. niger, A. fumigatus, Moniliella suaveolens and Epicoccum nigrum. Fungi that grows on sample D (no brand) there are 2 species namely, A. ochraceus and A. terreus.

Keywords: xerophilic, powder herb medicines, 'pegal linu' 


\section{PENDAHULUAN}

Jamur xerofilik merupakan kelompok jamur yang mampu bertahan hidup pada kondisi lingkungan yang kering. Jamur xerofilik sering tumbuh pada produk yang kering, seperti jamu serbuk, kacang-kacangan, rempah-rempah.

Produk yang terkontaminasi jamur xerofilik berpotensi mengandung mikotoksin, karena beberapa jenis jamur xerofilik mampu menghasilkan mikotoksin. Penghasil mikotoksin yang utama pada umumnya berasal dari genera Aspergillus, Penicillium dan Fusarium. Konsumen jamu umumnya mengkonsumsi jamu dalam jangka waktu lama, bahkan mungkin dalam waktu bertahun-tahun. Mikotoksin secara tidak sengaja bisa ikut tertelan masuk tubuh. Konsumen yang terpapar mikotoksin akan menurun kualitas kesehatannya antara lain penurunan daya tahan tubuh, mudah terserang penyakit, memicu terjadinya kanker, bahkan kematian (Samson et al. 1984).

Salah satu produk kering yang cukup banyak dikonsumsi masyarakat adalah jamu serbuk. Pengobatan tradisional jamu yang menggunakan bahan dasar tanaman obat mempunyai beberapa keuntungan, yaitu aman dan toksisitasnya yang rendah (Suharmiati dan Handayani, 2006). Alasan di atas yang menyebabkan konsumsi jamu dewasa ini meningkat. Menurut Kemenkes-BPPT (2010) saat ini sekitar 80\% populasi dunia di negara berkembang masih mengkonsumsi jamu, untuk menjaga kesehatan maupun kecantikan.

Jamu serbuk yang beredar dan dikonsumsi oleh masyarakat harus memenuhi standar kualitas dan keamanannya secara mikrobiologis untuk dikonsumsi. Hal tersebut didasarkan pada ketentuan dari BPOM sehingga jamu perlu diuji dan dianalisis kelayakan konsumsinya berdasarkan kualitas mikrobiologinya. Jamu serbuk umumnya mengandung bahan nabati yang dapat terkontaminasi oleh kapang (Makfoeld, 1993). BPOM telah menetapkan batas cemaran maksimal kapang untuk jamu serbuk yaitu $\leq 104 \mathrm{cfu} / \mathrm{g}$.
Salah satu jenis jamu yang banyak diminati masyarakat adalah jamu serbuk pegal linu. Jamu serbuk pegal linu dikonsumsi masyarakat sebagai upaya menghilangkan keletihan dan menjaga kebugaran tubuh. Di daerah Mojosongo, Surakarta ada banyak jenis jamu serbuk pegal linu baik yang ber merk maupun tidak ber merk.

Penelitian ini bertujuan untuk mengetahui ada tidaknya kontaminasi jamur xerofilik pada jamu pegal linu di Mojosongo, Surakarta dan mengidentifikasikan jenis-jenisnya.

\section{METODE PENELITIAN}

\section{Bahan :}

Bahan yang digunakan dalam penelitian ini adalah medium DG18, gliserol, aquadest, aquadest steril, Lactophenol Cotton Blue, alkohol pekat dan alkohol 70\%.

\section{Sampel :}

Sampel yang digunakan dalam penelitian ini adalah 4 jenis jamu serbuk pegal linu yang ada di wilayah Mojosongo, Surakarta terdiri dari 2 sampel jamu yang ber merk (sampel A dan B) dan 2 sampel jamu tidak ber merk (sampel $C$ dan D).

\section{Alat-alat yang digunakan:}

Otoklaf, entkas, gunting, api spirtus, jarum Ose, spuit steril, tabung reaksi, cawan Petri, mikroskop binokuler, obyeck dan deck glass.

\section{Prosedur Penelitian :}

\section{a. Persiapan suspensi dan pengenceran sampel}

Masing masing sampel jamu serbuk pegal linu diambil 1 gram dan dilarutkan dalam $9 \mathrm{ml}$ aquadest tingkat pengenceran $10^{-1}$. Setelah itu, dilakukan pengenceran secara bertingkat sehingga diperoleh pengenceran pada tingkat $10^{-2}$, $10^{-3}, 10^{-4}$.

\section{b. Inokulasi dan Inkubasi Sampel}

Suspensi sampel masing-masing pengen- 
ceran diinokulasikan sebanyak $0,1 \mathrm{ml}$ pada medium DG 18, kemudian diinkubasi pada suhu $25^{\circ} \mathrm{C}$ selama 3-5 hari.

\section{c. Pembuatan Preparat dan Identifikasi Jamur xerofilik}

Identifikasi jamur xerofilik dilakukan dengan membuat preparat jamur menggunakan metode Slide culture. Setelah itu dilakukan pengamatan ciri mikroskopis. Hasil pengamatan dirujukkan pada buku kunci identifikasi fungi yaitu "Introduction to Food-Born Fungi" (Samson, 1984) dan "Fungi and Food Spoilage" (Pitt dan Hocking, 1985), untuk menentukan nama spesies jamur xerofilik yang ditemukan pada sampel sediaan jamu serbuk pegal linu.

\section{Hasil dan Pembahasan}

Pengamatan pada 4 sampel jamu serbuk pegal linu yang terdiri dari 2 sampel jamu serbuk pegal linu bermerk (sampel A dan B) dan 2 sampel jamu pegal linu tidak ber merk (C dan D) di wilayah Surakarta didapatkan hasil: pada sampel A (ber merk) ditemukan ada 4 jenis jamur yaitu, E. chevalieri, E. amstlelodami, E. herbariorum dan E. repens. Jamur yang tumbuh pada sampel B (ber merk) ada 7 jenis yaitu, Eurotium repens, Eurotium chevalieri, Eurotium amstelodami, Aspergillus niger, Fusarium solani, Absidia corymbifera, dan Neosatorya fisheri. Jamur yang tumbuh pada sampel $\mathrm{C}$ (tidak ber merk) ada 6 jenis yaitu, Eurotium repens, A. candidus, A. niger, A. fumigatus, Moniliella suaveolens dan Epicoccum nigrum. Jamur yang tumbuh pada sampel D (tidak ber merk) ada 2 jenis yaitu, A. ochraceus dan $A$. terreus.

Jamu serbuk pegal linu merupakan jamu

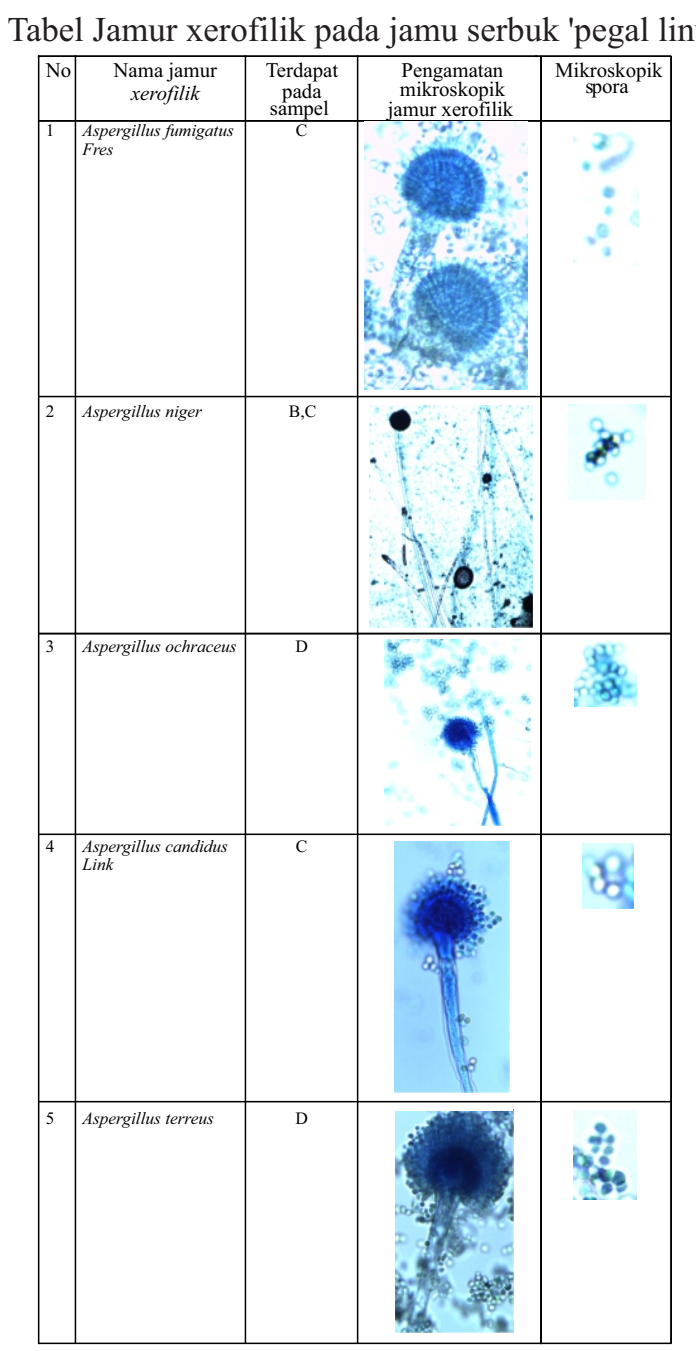




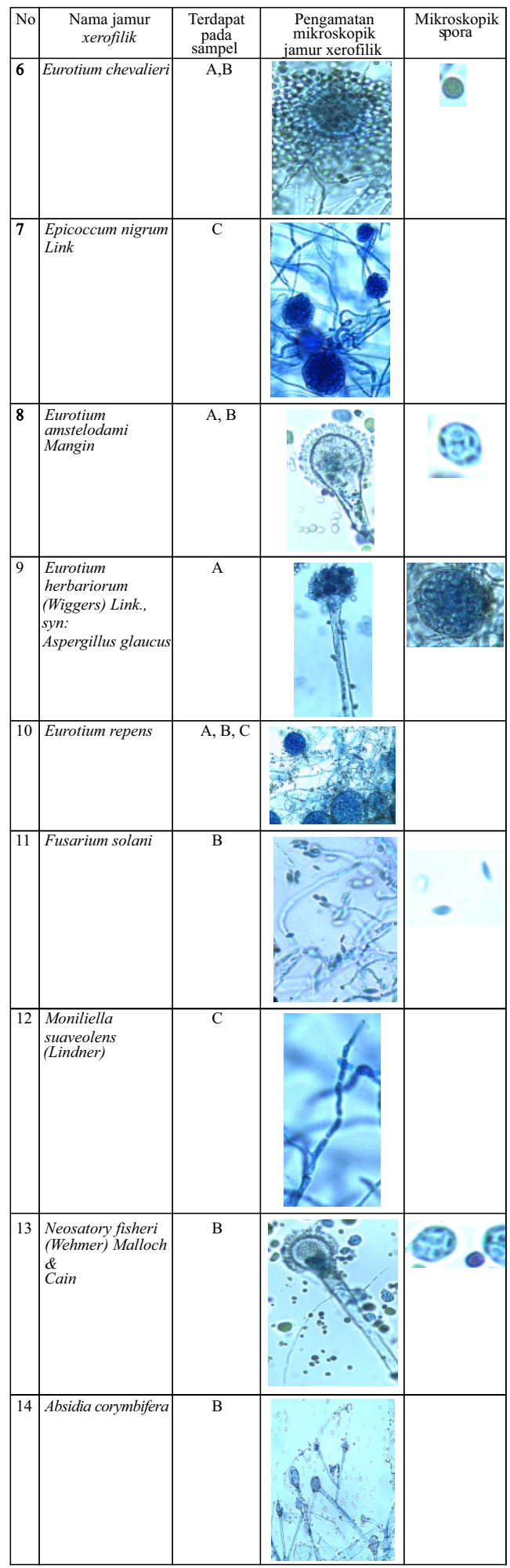

yang cukup banyak di konsumsi oleh masyarakat. Jamu serbuk merupakan produk kering yang masih ada kemungkinan terkontaminasi oleh spora jamur golongan xerofilik yang bisa tetap hidup pada kadar air yang rendah. Beberapa jenis jamur xerofilik mempunyai kemampuan menghasilkan mikotoksin yang dapat membahayakan konsumen. Untuk itu kami melakukan penelitian ada tidaknya jamur xerofilik pada beberapa jamu serbuk pegal linu yang ada di Mojosongo, Surakarta. Sampel diambil secara acak. Sampel yang diteliti terdiri dari 2 sampel jamu bermerk (sampel A dan B) serta 2 sampel jamu tidak ber merk (sampel $C$ dan D). 
Masing-masing sampel jamu diinkubasi pada medium DG 18 dan dilakukan secara duplo.

Hasil inkubasi ke empat sampel jamu pegal linu bermerk dan tidak ber merk, semuanya menunjukkan adanya pertumbuhan jamur xerofilik. Pada sampel A (ber merk) ditemukan ada 4 jenis jamur yaitu, E. chevalieri, E. amstlelodami, E. herbariorum dan E. repens. Jamur yang tumbuh pada sampel B (ber merk) ada 7 jenis yaitu, Eurotium repens, Eurotium chevalieri, Eurotium amstelodami, Aspergillus niger, Fusarium solani, Absidia corymbifera, Neosatorya fisheri. Jamur yang tumbuh pada sampel C (tidak ber merk) ada 6 jenis yaitu, Eurotium repens, A. candidus, Aspergillus niger, Aspergillus fumigatus, Moniliella suaveolens dan Epicoccum nigrum. Jamur yang tumbuh pada sampel D (tidak ber merk) ada 2 jenis yaitu, Aspergillus ochraceus dan Aspergillus terreus.

Dari hasil penelitian ini terbukti bahwa secara mikologis jamu yang tidak ber merk belum tentu kualitasnya lebih rendah dibandingkan dengan jamu yang ber merk. Hal ini terbukti dari jumlah koloni yang tumbuh pada jamu tidak ber merk lebih sedikit dibandingkan jumlah koloni pada jamu ber merk. Ditinjau dari jenis jamur yang tumbuh pada masing-masing sampel jamu, tidak semua berpotensi menghasilkan mikotoksin. Jamur yang berpotensi menghasilkan mikotoksin adalah: A. candidus, A, fumigatus, $A$. ochraceus dan A. niger dan Eurotium sp (Rukmi, 2009).

Jamu sampel A (ber merk) ditumbuhi oleh 4 jenis jamur yaitu E. chevalieri, E. amstlelodami, E. herbariorum dan E. repens. Jenis-jenis jamur ini berpotensi menghasilkan mikotoksin. Jamu sampel B (ber merk), sampel C (tidak ber merk) dan sampel D (tidak ber merk) ditumbuhi jamur golongan Aspergillus yang berpotensi menghasilkan mikotoksin. Dengan demikian produsen sampel jamu A, B, C dan D perlu memperbaiki proses produksi jamunya. Kontaminasi jamur bisa terjadi dari bahan baku jamu, proses pengeringan proses produksi ataupun pengemasan. Simplisia jamu menandung karbohidrat dan protein yang bisa dimanfaatkan oleh jamur untuk dijadikan sumber energi. Jenis jamur yang paling frekuensinya paling banyak ditemukan adalah $E$. repens dan yang frekuensinya paling banyak kedua adalah $A$. niger. Hal ini sesuai dengan pernyataan Pitt dalam Rahmadi (2016), bahwa pada penyimpanan dalam waktu yang lama, produk pertanian kering dapat terinfeksi oleh Aspergillus niger dan Eurotium sp.

Dari hasil penelitian Isnawati dkk (2002), yang meneliti kontaminasi jamur pada simplisia di pabrik jamu di pulau jawa menunjukkan bahwa simplisia yang dipakai tidak memenuhi batas persyaratan Kepmenkes No.661/ MENKES/SK/VII/1994. Hasil penelitian ini senada dengan penelitian yang dilakukan oleh Rukmini (2009) terhadap simplisia jamu di penjual obat tradisional di pasar dan toko bahan obat di Semarang, dimana hasilnya menunjukkan simplisia-simplisia tersebut mengandung 16 jenis Aspergillus dan 9 jenis di antaranya menghasilkan Aflatoksin.

Dari hasil penelitian ini disarankan pada produsen jamu agar lebih memperhatikan faktor kebersihan baik pada bahan baku simplisia, penyimpanan bahan baku, pengolahan produk dan pengemasan. Adanya kontaminasi/cemaran jamur xerofilik terutama yang berpotensi menghasilkan mikotoksin bisa menimbulkan masalah gangguan kesehatan bagi konsumen dimana konsumen biasanya mengkonsumsi jamu hanya disedu dengan air hangat-hangat kuku sehingga spora jamur belum mati.

\section{KESIMPULAN}

Dari hasil penelitian ini disimpulkan bahwa pada ke empat sampel jamu baik yang ber merk maupun tidak ber merk terdapat kontaminasi/ cemaran jamur xerofilik. Jenis-jenis jamur yang didapatkan adalah: Pada sampel A (ber merk) ditemukan ada 4 jenis jamur yaitu, E. chevalieri, E. amstlelodami, E. Herbariorum dan E. 
repens. Jamur yang tumbuh pada sampel B (ber merk) ada 7 jenis yaitu, Eurotium repens, Eurotium chevalieri, Eurotium amstelodami, Aspergillus niger, Fusarium solani, Absidia corymbifera, Neosatorya fisheri. Jamur yang tumbuh pada sampel $\mathrm{C}$ (tidak ber merk) ada 6 jenis yaitu, Eurotium repens, A. candidus, Aspergillus niger, Aspergillus fumigatus, Moniliella suaveolens dan Epicoccum nigrum. Jamur yang tumbuh pada sampel D (tidak ber merk) ada 2 jenis yaitu, Aspergillus ochraceus dan Aspergillus terreus.

\section{UCAPAN TERIMA KASIH}

Ucapan terimakasih disampaikan kepada Yayasan Setia Budi dan LPPM Universitas Setia Budi yang telah memberikan kesempatan sehingga penelitian ini dapat berjalan dengan lancar. Selain itu kami ucapkan terima kasih banyak pada staf laboratorium Mikologi Universitas Setia Budi yang telah banyak membantu proses isolasi dan identifikasi jamur xerofilik ini.

\section{DAFTAR PUSTAKA}

Askun, T., Elfem, R., dan Taskin, E, 2007. "Comparison of Rose Bengal Chloramphenicol Agar and Dichloran Glycerol Agar (DG18) for Enumeration and Isolation of Moulds from Raisins". Journal of Applied Biological Sciences, 1 (2): $71-74$.

Isnawati A., Mutiatikum D., Nikmah 2002. Gambaran Cemaran Jamur, Jamur Aspergillus flavus dan Aflatoksin pada Simplisia dari Pabrik Jamu di Pulau Jawa.

Kementerian Kesehatan Republik Indonesia. 2010. Riset Kesehatan Dasar. Jakarta: Badan Penelitian dan Pengembangan Kesehatan

Makfoeld, Dj. 1993. Mikotoksin Pangan. Yogyakarta:Penerbit Kanisius

Pitt, J.I. \& Hocking A.D., 1985. Fungi and Food Spoilage. Tokyo: Academic Press Australia.

Rahmadi A. 2016. Isolasi Jamur Potensial Penghasil Mikotoksin Pada Produk Fermentasi Biji Kakao Kering asal Indonesia Isolation of potential mycotoxigenic moulds in fermented and dried cocoa beans from Indonesia.

Rukmi. I. 2009. Keanekaragaman Aspergillus pada Berbagai Simplisia Jamu Tradisional. Jurnal Sains \& Matematika (JSM). Vol.17 Nomor 2 April 2009. Hal. 82-86.

Samson R.R., Hoekstra E.S., Oorschot C.A.N. 1984 Introduction to Food-Born Fungi. Centraalbureau Voor Schimmelcultures. Institute of the Royal Netherlands Academy of Art and science

Suharmiati dan Handayani, L., 2006. Cara Benar Meracik Obat Tradisional. Jakarta: Agro Pustaka 